\title{
TRADITIONAL LAW UNDER FRENCH COLONIAL RULE ${ }^{1}$
}

\author{
By KwaME OPOKU
}

Although assimilation had been the dominant theme of French colonial policy, it gave way to other solutions when faced with the reality ${ }^{2}$. French law could not be applied in toto to the inhabitants of West Africa who had no reason to prefer a foreign law to their own traditional system. The French therefore embarked on a policy of the maintenance of traditional law and institutions which found expression in the distinction between persons of "statut civil français" and those of "statut personnel".

Generally speaking, all Frenchmen (and women) had the "statut civil français" and Africans, unless they had been granted French citizenship, had the "statut personnel" and were governed by their own customary law. African customary law was variously styled by French jurists and the colonial legislator- "statut local", "statut reservé", statut indigène" and "statut personnel". Those who had the "statut civil français" were subject to French law, including not only the "Code Civil" but also the "Code de Commerce", "Code Pénal" and de "Code d'Instruction Criminelle". There was also the vast body of French administrative law ("droit administratif") and case-law ("la jurisprudence"). But the application of French law to the colonies was by no means automatic. Metropolitan codes and laws applied only to the extent that they had been made applicable in the colonies by decree ${ }^{3}$.

We shall discuss in this article, which is limited to the colonial situation in French West Africa, the exceptional legal position of the inhabitants of Senegal, the methods by which Africans could acquire French citizenship, the respective domains of the two "statuts" and the concept of "ordre public" as it applied in the colonies.

\section{The Position of the Inhabitants of the Four Communes of Senegal}

Before 1946 the distinction between "statut civil français" and "statut personnel" corresponded to that of citizen and non-citizen. Under the "Ancien Régime",

\footnotetext{
1 See also, J. Chabas, "La justice indigène en Afrique Occidentale Française", Annales Africaine, 1954, 91-151; "I a justice française en Afrique Occidentale Française", Annales Africaines, 1955, 79-108; P-F. Gonidec, Les droits africains, Paris, L.G.D.J., 1968; P. Lampué, Droit d'Outre-Mer, Paris, Dalioz, 1959; F. Luchaire, Droit d'Outre-Mer, Paris, Press Universitaires de France, 1959; K. Opoku, L'évolution du droit traditionnel dans les pays francophones et anglophones de l'Afrique Occidentale, Thèse, Doctorat en Droit, Aix-Marseille, 1970; A. Robert, "Attitude du législateur français en face du droit coutumier d'Afrique Noire", L'Avenir du droit coutumier en Afrique (1956) Universitaire Pers Leiden, 170-189.

2 On French colonial doctrines and practice, see R. F. Betts, Assimilation and Association in French Colonial Theory, 1890-1914, New York, Columbia University Press, 1961; H. Brunschwig, Mythes et réalités de l'impérialisme colonial français 1871-1914, Paris, 1960; M. Crowder, West Africa Under Colonial Rule, London, Hutchinson, 1968; Deschamps, Méthodes et doctrines coloniales de la France, Paris, A. Colin, 1953; F. Fanon, Les damnés de la terre, Paris, Maspero, 1961; G. Hardy, Histoire sociale de la cclonisation française, Paris, Larose, 1953; J. Hargreaves, West Africa: The Former French States, New Jersey, Prentice Hall, 1967; A. Memmi, Portrait du colonisé, précédé du portrait du colonisateur, Paris, 1966.

3 On the application of French law in the colonies, see Lampué, "Les lois applicables dans les territoires d'outre-mer", Penant, 1950, D. 1.; Luchaire, "Quelles sont les lois applicables de plein droit dans la France d'outre-mer?", Dalloz, 1950, Chron. p. 135; Camerlynck and Decottignies, Code Civil de l'Union Française, 1950.
} 
those Africans who embraced Christianity became French citizens with full rights and a decree of the Convention of 16 pluviose of the year II reduced some of the disadvantages attached to the status of non-citizen. A law of 24 April 1833 abolished the serious disabilities imposed on the inhabitants of the colonies. Article 1 of the Act provided that: "Every person born free or having lawfully acquired his freedom shall enjoy in the French colonies, civil and political rights under the conditions prescribed by law". Article II abolished all the restrictions which had been placed on the enjoyment of civil and political rights by freed men. The predominant colonial policy at this period was assimilation but it should be rembered that French rule at this time extended only to the four communes of Senegal. The application of the law of 1833 did not raise any problems in the colonies of Guiana, Reunion and St. Pierre et Miquelon, colonies inhabited mainly by persons of European extraction or which had no recognized customary law system. However, difficulties arose in the application of this Act to the four communes of Senegal, namely, Dakar, Goree, St. Louis and Rufisque. The political rights of the inhabitants of these communes had been recognized by case-law ${ }^{5}$. According to the "Cour de Cassation", these rights were not derived from the 1833 law but from special legislation expressly passed for that purpose. The main question was whether the law of 1833, by conferring civil and political rights on the inhabitants of the colonies, had not thereby abolished their "statut personnel". Judicial interpretation of the Act was to the effect that it did not abolish the "statut personnel" nor did it impose the "statut civil français". The inhabitants of those communes could maintain their customary law for matters falling within the "statut personnel".

Several earlier decrees had reserved to these Senegalese their customary law ${ }^{7}$. A new law was passed on 29 September 1916, stating that: "The natives of the four communes of full powers and their descendants are and remain French citizens subject to the military obligations mentioned in the Law of 19 October 19158." This Act was given various interpretations. In one case an African had been accused of various offences and the question was whether he was subject to the jurisdiction of the French court ${ }^{9}$. This depended on the status of the accused. On it being established that the mother of the accused was a native of one of the four communes, it was held that he was subject to the jurisdiction of the French courts. It was true, the court said, that the accused himself was not born in St. Louis but he still had the status of a French citizen since the law of 1916 applied not only to the inhabitants of those communes but also to their descendants. In another case, it was held that the law of 1916 applied only in the case of paternal descent ${ }^{10}$. According to the Cour d'appel of Dakar, in both Islamic and French law a child takes the nationality of the father. A child born outside the four communes, of a

\footnotetext{
4 Loi du 24 avril, 1833. Art. I-Toute personne née libre ou légalement ayant acquis a liberté, jouit dans les colonies, (i) des droits civils, (ii) des droits politiques, sous les conditions pescrites par les lois. Art. II-Sont abrogées toutes dispositions de lois, édits, déclarations du rois, ordonnances royales et notamment toutes restrictions et exclusions qui avaient été prononcées, quant à l'exercise des droits civils et des droits politiques, à l'égard des hommes de couleur libres et des affranchis.

5 Cass. Civ. 24 juillet, 1907, Penant 1908 I, 362; Cass. Civ. 22 juillet, 1908, Penant 1908 I, 395; Cass. Civ. 26 avril, 1908, Penant 1909 I, 350; Cass. Civ. 8 avril, 1910, Penant 1910, III, 231; Cass. Civ. 17 mai 1911

6 Penant 1912 III, 4 .

6 Cons. d'Etat, 4 décembre 1936, Rec.Lebon, 1060; 13 mai 1927 Penant 1928,

8 See the decision of the Cour d'appel de Dakar, 15 January 1915, Penant 1915, 155 (Lieutnant-Gouverneur du Ś́négale. A. Diouf).

9 Cour d'appel de l'A.O.F. 17 août, 1921, Ministère Public c. Papa N'Diaye, Penant 1922, 101.

10 Cour d'appel de l'A.O.F., 5 septembre, 1924, Penant, 1925, 2.
} 
Muslim father (himself born outside the communes) could not be considered a French citizen and thereby have his birth recorded in the French register of births. The birth of an elder son had been recorded since he had been born in St. Louis. Thus the place of birth assumed great importance in this matter. There was no ground, at least from the reading of the 1916 law, for restricting the effect of the law to paternal affiliation. One reason advanced for this decision was the principle of the maintenance of customary law and institutions ${ }^{11}$. This is not tenable since the maintenance of traditional institutions was not incompatible with the grant of citizenship. In any case, it was not contrary to French colonial policy to further the accession to "statut civil français" by persons of "statut personnel". The reliance on Islamic law to determine the extent of a French decree conferring citizenship on French subjects in a French colony was, to say the least, curious.

However, it cannot be said that the courts generally tended to restrict the number of persons capable of taking advantage of this Act. The same court had held in another case that the acquisition of French citizenship by Africans was no obstacle to their retaining their "statut personnel12".

Though several decisions affirmed the principle that the 1916 Act did not abolish the right of the inhabitants of Senegal to regulate their affairs in accordance with customary law, there still lingered some doubts and a decision of the Cour d'appel of Dakar had to settle the point finally'13. The court held that neither the law of 24 April 1833 nor the decree of 5 November 1830 (which promulgated the Code Civil in Senegal) imposed the "statut civil français" on the inhabitants of Senegal. Nor did the law of 1916 withdraw the "statut personnel" from the Muslims of the four communes. The Act had effect only in the military sphere and did not modify any civil status. So on the facts of the case before the court, the succession to the property of a Muslim from one one of the communes ought to be regulated by Islamic law. This interpretation was based on the obvious intention of the legislator. France wanted more soldiers for the 1914-18 war and it was considered desirable to enrol some Africans in the French army. The grant of citizenship was to facilitate enlistment into the army.

The position of the inhabitants of the four communes in Senegal was that they had French citizenship but could maintain their customary law. In public law they were governed by French law but in private law, they were subject to traditional law unless they had renounced it. This principle was embodied in several decrees ${ }^{14}$. The difference between the position of the inhabitants of the four communes and that of all the Africans in what was later known as the Federation of French West Africa, was that, whereas the former were considered to be French citizens by birth and in principle subject to French law, the latter were non-citizens and subject to customary law. The latter could acquire French citizenship by methods which will be described below.

11 “Considérant que la France a déclaré respecter les usages et l'ordre indigènes en tout ce qui n'est pas contraire à la civilisation et à l'ordre public: considérant qu'il résult d'une consultation du Cadi de Dakar versée au dossier qu'en droit musulman au Sénégal comme cela existe d'ailleurs en droit français, l'enfant suit la condition du père.. Considérant, par suite que le jeune $Z$ est indigène musulman non-citoyen français" (Penant, 1925, p. 11).

12 Decision of 4 December 1925, Dareste 1925, 3.176.

132 avril, 1926, Penant 1926, 197.

13 Decrees of 10 November 1903 (Penant 1904, III, 17); 22 May 1905 (Penant 1905, III, 160); 29 January 1907 (Penant 1907, III, 86); 25 April 1910 (Penant 1910, III, 154); 16 August 1912 (Penant 1912, III, 182); 9 March 1914 ('enant 1914, III, 191). 


\section{Methods by which Africans could acquire French citizenship}

An African could become subject to French law either by becoming a French citizen or, without acquiring French citizenship, by renouncing his "statut personnel". Two methods existed for the acquisition of cizenship, namely, by a decree of the President of the French Republic and by a judicial decision. Noncitizens could also occasionally become subject to French law where an option was open to them.

\section{A. Admission to Citizenship by Decree}

A decree of 25 May 1912 recognized the possibility of the inhabitants of French West Africa acquiring French citizenship ${ }^{15}$. This decree laid down the necessary conditions for citizenship, and, since most of the questions on this matter involved the interpretation of this decree, we reproduced the text here:

Art. I. Any French subject born and domiciled in the territory of French West Africa can on his demand, after attaining the age of twenty-one years, acceed to French citizenship by fulfilling the following conditions:

(a) $\mathrm{He}$ must prove his devotion to the French cause or prove that he has occupied for at least ten years a post in a French enterprise, public or private;

(b) He must know how to read and write French;

(c) He must establish that he has a means of livelihood and that he is of good character and manners.

Art. II. The conditions under which the person making the request shall establish that he fulfills the conditions of Art. I shall be determined by decree of the Governor-General. The following persons need not prove they have knowledge of the French language: natives decorated with the Legion of Honour or with military medals and those who have rendered service to France or the colony.

Art. III A French subject who intends to acquire French citizenship must present himself either before the mayor of the commune of his domicile or before the administrator of the "cercle" in which he resides, to make his request and declare that he intends to be governed by the civil and political laws governing French citizens. He must attach to his request:

(a) A birth certificate or a judicial document to that effect;

(b) An official document establishing that he has been domiciled for at least three years in the commune or "cercle" where he makes his request;

(c) A declaration must be recorded in which he formally renounces the benefit of his "statut personnel". If he has been married according to French law, he must also add the marriage certificate and, failing that, the birth certificate of his living children.

Art. IV The mayor or administrator shall make a report on the request and, after inquiry, shall send it to the Lieutenant-Governor who shall transmit it with his remarks to the Governor-General. The latter shall send it to the "conseil de gouvernement" which shall transmit it with the file to the Minister for the

15 Penant 1912, III, 226. 
Colonies. The President of the Republic deals with the matter on the proposition of the Minister for the Colonies and the Minister of Justice.

Art. V No fees shall be charged for admission to citizenship.

Art. VI The accession of French subjects of French West Africa to French citizenship is personal. Nevertheless a woman married according to French law takes the status .of her husband. The issue of such a union also follow the status of the father and shall be included in the register for French citizens.

Another decree was passed on 14 January 1918 to compensate those subjects of French West Africa who had fought for France in the 1914-18 war by granting them citizenship" ${ }^{16}$. Those who were decorated with a medal and "Croix de guerre" could obtain citizenship for themselves as well as for their wives and children, provided that they had not participated in any act directed against French rule nor been deprived of their civil and political rights. The procedure was the same as that laid down by the decree of 1912 .

Even when the conditions mentioned in the 1912 decree had been fulfilled, the government determined admission to citizenship in each individual case according to discretion. The whole procedure was cumbersome and lenthy. The dossier had to pass from the Mayor of the commune to the Lieutenant-Governor (at the capital of the territory), to the Governor-General at Dakar, then to the Minister of Justice and finally to the President of the French Republic.

\section{B. Admission to Citizenship by Judgment of the Court}

This second procedure was often employed concurrently with the first ${ }^{17}$. The conditions were the same as in the first procedure except that in this case the possession of a diploma or decoration was insisted upon. Given the inadequate facilities for education in the colonies, this method of acquiring citizenship could only be resorted to by a very small élite. Professor Crowder declares that „Statistics bear out how small the efforts of the Colonial Governments and missionaries in the field of education were before 1939". (Op. cit. 374). In one school in Bamako, for instance, one teacher was in charge of a class of 200 pupils. Secondary education in the French colonies was equally bad. For a population of eleven million, there were only two secondary schools (the Lycée Faidherbe at St. Louis and the Ecole Normale William Ponty in Dakar) and they admitted between fifty and eighty boys a year. The restriction of the number of educated elements in the colonies fitted the basic French colonial policy: "The French trained a small élite under a system which stressed the importance of loyalty to France. This élite was absorbed into the colonial system, and was sufficiently small to present no threat to white society. The French were well aware of the dangers a large unemployed intelligentsia could present to their position" (Crowder).

16 Penant 1918, 87.

17 Decree of 23 July 1937, Penant 1938, 107. 


\section{Effects of Accession to Citizenship}

The main effect of accession to French citizenship was that, the African became thenceforth subject to French law. Except in cases where there could be an option of legislation or jurisdiction, he had to submit all his disputes to the French courts to be decided in accordance with French law. Thus he could no longer claim the benefit of any law or custom which formed part of his former "statut personnel". In one case, the plaintiff, who formally had a "status personnel", opposed in his capacity as representative of an African community of which he used to be head, the request for registration of title to land made by the defendant ${ }^{18}$. His opposition was rejected on the ground that an African who acquired French citizenship lost his "statut personnel" and all the rights and duties that such a status implied. Thus without an express mandate, he could not be admitted in a French court to represent an African community. The court relied on article 3 of the decree of 1912 which required that a person making an application for French citizenship must present a formal declaration in which he formally renounces the benefit of his "statut personnel". A person could not be allowed to renounce a status and then later on claim the benefits and privileges attached thereto. In the case before the court, an African chief who had not renounced his "statut personnel" would have been allowed to represent his community without the necessity of producing a formal mandate.

We have mentioned that admission to citizenship was on individual basis. Thus the wife and children of an African acceding to citizenship were not affected unless there had been a marriage celebrated in accordance with French law. This meant that where two persons subject to customary law married under that system, had a child and the father later acquired French citizenship, neither the wife nor the child could claim citizenship merely by virtue of their relationship with the man. Such claims of citizenship were declared to be excluded by article 6 of the decree of $1912^{19}$. This situation was changed by the decree of 1918 which allowed a man who acquired citizenship to secure the same status for his wife and children. If the children were over sixteen years of age their express consent was necessary for this change of status. A decree was passed in 1935 providing for accession to citizenship of legitimate children of less than eighteen years of age whose father acquired French citizenship after their birth, and also for children legally recognized by their father before the change of status ${ }^{20}$. Finally, a decree of 1937 accorded French citizenship to the wife and legitimate issue of a person acquiring citizenship ${ }^{21}$.

The status of children depended on the attitude the courts took towards the marriage of their parents. The Cour d'appel held a customary law marriage celebrated before admission into citizenship as producing the same effects as a marriage celebrated at the registry and therefore exempted the parties from a

18 J. A. c. Dame O. T. et Ministère Public, Trib. de Première Instance de Cotonou, 25 janvier, 1921, Penant 1921. Under the system of land registration in the French colonies, a demand for registration of title to a land hitherto subject to customary law could be opposed in the courts. For a full discussion on this question, see Opoku, 'L'évolution du droit foncier en Afrique Occidentale ${ }^{\alpha}$, in Verfassung und Recht in Ubersee, 1973, 385-405.

19 The court reached a similar conclusion in the case of a child born before his father acquired citizenship and outside marriage: Cour d'appel d'A.O.F. 20 juin, 1930 Ministère Public c. André François Yacé.

20 Decree of 25 . August 1935, Penant 1936, 53.

21 Decree of 23 July 1937, Penant 1938, 102. 
second ceremony before the registry ${ }^{22}$. The court thus admitted by implication that a marriage valid by customary law would be recognized for the purposes of the decree of 1937.

\section{Renunciation of the "statut personnel"}

Although not a method of admission to citizenship, the renunciation of the "statut personnel" had the same effect as accession to citizenship, so far as private law is concerned. The African who renounced his "statut personnel" was no longer subject to customary law. But this submission to French law did not imply an automatic acquisition of the political rights of a French citizen. Renunciation was total and irrevocable. It should be distinguished from the partial renunciation which could be made at the conclusion of a contract or some legal transaction. It must also be distinguished from the renunciation of the jurisdiction of the customary law courts and submission to the jurisdiction of the French courts.

The procedure for renunciation was much simpler than the two methods of acquiring citizenship. Neither an administrative act nor a judicial decision was required. A simple declaration was to be made voluntarily by the person who wanted to acquire the "statut civil français". This declaration could be made before either the registrar ("officier de l'état civil") of the domicile of the declarant, or before a justice of the peace, assisted by clerk of the court and in the presence of two witnesses, or before a notary. A minor could make use of this procedure, in which case he had to be assisted by the person whose consent was necessary for his marriage.

An interesting question concerning renunciation was whether renunciation of a religion which formed the basis of a legal status, for example, Islam, involved a change of legal status. Apart from Islam, most of the other religions, for example, Catholicism, had no recognized legal status although most of the persons who had the "statut civil personnel" were either Catholics or Protestants. The courts took a clear position on the matter in the case of Femme Koromaka contre le mari Kamara ${ }^{23}$. A lady brought a petition against her husband; the lower court held that an African Catholic could insist that his marriage be determined by different considerations, whereas the court of appeal-which applied primarily French law but also heard appeals from the customary courts-denied the existence of a coutume catholique and declared that the Catholic religion did not confer on those Africans who embraced it a special status or new civil rights contrary to their ancestral customary law. A religious marriage, the court declared, did not produce any civil effect with respect to either French law or customary law; a customary court could not entertain a demand for divorce based on the alleged Catholic custom, since there was in fact no marriage at all. The parties' so-called marriage was not in accordance with either French or customary law. In reading this case we must not overlook the long history of struggle between the state and church in France. The French courts have in general refused to recognize the jurisdiction of religious authorities in matrimonial matters. Penalties are provided by French

22 Cour d'appel de Dakar, 19 novembre, 1948, Penant 1952, 12 (De Soza c. Dame de Souza).

23 Cour d'appel cie Dakar, 13 novembre, 1924, Penant, 1925, 101. 
law for cases where priests celebrate marriages without ensuring that there had been a prior civil ceremony. With this insistence on the civil nature of marriage, it would not have been easy for the courts in Africa to recognize a "religious custom".

\section{The Respective Domains of Application of French and African Law}

We have already mentioned the possibilities of passing from one legal status to another, but the existence of the two status raised another problem: the delineation of the respective domains. It had to be decided which law ought to apply when a transaction could be referred to either system. We have here the possibilities of conflict, firstly between the "statut civil français" and "statut personnel", and secondly between the various customary law systems. Our concern here is with the first type of conflict.

It has already been mentioned that the determination of the law applicable in any particular case depended on the status of the parties involved. If the parties had the "statut civil français", then French law applied. If they had the "statut personnel" then customary law was applicable. However, there were certain cases in which French law was the applicable law even though one or both parties were of "statut personnel". In addition, the concept of "ordre public" was sometimes used to set limits to the application of customary law.

\section{A. The Application of French Law by Express Legislative Enactment}

Legislation often provided that French law should apply to persons who in other matters were governed by customary law. For example, the application of customary law to the inhabitants of the four communes of Senegal was limited to questions of marriage, wills, succession and donations, since these fell within the "statut reservé" mentioned in the decrees of 20 May 1857 and 20 November 1932. In all other matters, they were governed by French law.

\section{B. Application of French law where one of the parties is French}

The general principle was that whenever a Frenchman and a person of "statut personnel" were involved in a legal transaction, French law was to govern the transaction. One explanation for this principle, advanced by those who support it, was that French law was the common law of the state and not the law of a minority. Thus it was a law of general application upon which exceptional laws, such as African traditional law, have been grafted. That was why it was possible to pass from the "statut personnel" to "statut civil français" without the reverse process being possible. The absurdity of such reasoning is so obvious that we shall not spend any time in refuting it. Suffice to mention that French law was in reality the exceptional law in so far as it applied to a tiny minority in the colonies. 
The general principle was found in the decree dealing with judicial organization in the colonies ${ }^{24}$. The result of this principle was that French law became applicable to the African who came into contact with Frenchmen. In any case in which a Frenchmann was the victim of a wrongful act, French law was applicable. Thus in one case where an African of "statut personnel" stole postal packets destined for Europeans it was held that only the French courts had jurisdiction ${ }^{25}$. In any case in which the civil responsibility of a French man might be involved, either directly or indirectly, only a French court had jurisdiction. For example, in one case homicide had been comitted through the negligence of an African, the victim was an African and the employer of the accused, who was liable, was also an African but insured by a French insurance company ${ }^{26}$. Thus in this case all the parties involved except the insurance company had the "statut personnel" and yet French law was applied simply because one of the parties had the "statut civil français". One effect of the contract of insurance covering the liability of an employer is to subrogate the assurer to the rights and actions of the assured as soon as the latter is accused of an injury caused to another person by his employee. Thus the African victim or his beneficiaries had a direct action against the French insurance company, an action which had to be taken before the French courts.

To the general rule that French law was the applicable law in cases where a Frenchman was involved, there were a few exceptions. In succession cases, if the deceased and his heirs were of a different status, the status of the deceased determined the law that was to govern the devolution of his property ${ }^{27}$.

The decrees on judicial organization stated that in cases of conflict, the matter could be taken to the courts of local law which, with the agreement of the parties, would apply customary law ${ }^{28}$. One important limitation on the right of a Frenchman to submit to customary law was where he sought to evade a law or an institution which was considered to be of "ordre public ${ }^{29}$ ". Thus the marriage by a Frenchman in accordance with customary law or Islamic law was always considered void ${ }^{30}$. A child born out of such a union would be illegitimate and, if the mother were an African, would have the "statut personnel".

Following the principle of the autonomy of the individual's will, it was admitted that, subject to article 6 of the Civil Code ("ordre public"), a Frenchman could agree to submit his contractual relations to customary law ${ }^{31}$. This would happen, for instance, if a Frenchman and a person of "statut personnel" entered into a contract and for some reason or other did not want to hasard their fortunes in the French courts.

\footnotetext{
24 Decrees of 16 November 1924, Art. 14 (Penant 1925, III, 88); 13 April 1921, Arts. 7 and 8 (Penant 1922, III, 43); 29 December 1922, Art. 3 (Penant 1925, III 145); 22 November 1922, Arts. 1, 3, 31, 33 and 34 (Penant 1923, III, 86).

25 Cour d'appel d'A. O. F., 24 mars, 1914: Ministère Public c. Bakary Bourval Trappe et autres, Penant 1914, 180; Cour d'appel d’A. O. F. 30 août, 1913: Cosme da Souza c. Ministère Public, Penant 1914, 273.

26 Cour d'appel d'A. O. F., 273. 10 décembre, 1936, Penant, 1938, 169.

27 Cour d'appel d'A. O. F., 2 février, 1917: N'Dioro Waly Dieng c. Becaye Kounta, Penant, 1917, 249; Cour de Cassation, $22 \mathrm{mai}, 1905$, Deves c. Yaktim Diagne, Penant, 1905, 295.

28 Decrees of 3 December, 1931; 22 March, 1924 and 16 August 1912.

29 Code Civil, Art. 6: “On ne peut pas déroger, par des conventions particulières, aux lois qui intéressent l'ordre public et les bonnes mœures"

30 Eugène Dipme c. Ministère Public, Cour d'appel d'A. O. F., 12 mars, 1920, Penant 1928, I. 222.

31 Decrees of 3 December 1931, Art. 8; 21 April 1933, Art. 8; 31 July 1927, Art. 43.
} 


\section{Application of French Law at the Option of the Parties}

French law could be applied in a particular case because the parties, even though subject to customary law, had elected for the application of French law. This option had to be made at the time of entering into a transaction and the right of option was embodied in several legislative enactments ${ }^{32}$. Since the option was limited to a particular matter, it could be repeated on any occasion at which persons entered into a legal transaction.

Option could be express or implied. In the former case, the person of "statut personnel" formally expressed his intention of submitting to French law, either by deed or by a declaration before a tribunal. Implied option arose when a person of "statut personnel" resorted to the French courts which almost invariably applied French law. Implied option also arose if, in the circumstances of the particular case, it could be implied that the parties intended to place their legal transaction under French law. A plaintiff, for instance, sought to have declared void a will which had been made by a Muslim before a "notaire" in Dakar"33. It was argued that since the deceased hat not renounced his "statut personnel" (Islamic law in this case) he could not make a will in the form prescribed by the Civil Code. Moreover, he had left his wife a greater portion of his property than he could lawfully do under Islamic law. The court upheld the argument that by making a will before a "notaire", an institution unknown to customary law, and by complying with the Civil Code, the deceased had shown an intention to submit his will to French law.

The Cour d'appel often warned that the intention to submit to French law should not be easily implied. Thus the fact that a Muslim woman gave her consent to the marriage of her son under French law could not be used as ground for inferring that she intended the devolution of her property to be governed by French $\mathrm{law}^{34}$. But the fact that an African took a policy of insurance covering motor accidents was held to be sufficient proof of his intention to subject himself to French law in any matter of civil liability concerning traffic accidents ${ }^{35}$.

At times the courts were strict with their insistence on formal agreements to take a case to the French courts and in the absence of such an agreement would declare themselves without jurisdiction to decide cases involving only parties who had the "statut personnel36" However, in 1954, the Cour d'appel at Abidjan reversed its own earlier decision by holding that persons of "statut personnel" could use the French courts even in the absence of such an agreement ${ }^{37}$.

As a general rule, the option was exercisable in civil and commercial matters. This was understood to mean any matter which depended primarily on the consent of the parties as, for example, contracts. The right of option was excluded from family law, especially in matters concerning marriage ${ }^{38}$, on the ground that to allow this freedom of choice in family law would amount to a partial abandonment

\footnotetext{
32 Decrees of 10 November 1903, Art. 15 (Penant 1904, III, 15); 16 August 1912, Art. 48 (Penant 1912, III, 282); 22 March 1924, Art. 66 (Penant, 1924, III, 144); 16 November 1925, Art. 14 (Penant, 1925, III, 88).

33 Mame Anna Seck, veuve Jean Thiam c. Meissa Bigue Seck et autres, Cour d'appel d'A. O. F., Penant 1929, 255.

34 Succession Yakhia Diagne c. Héritiers Dèves, Cour d'appel de Dakar, 1903, Penant $1903,57$.

35 Ebongue c. Edoukou, Chambre Spéciale d'homologation du Cameroun, 28 septembre, 1933, Penant $1934,157$.

36 Koffi Ayuini c. Tano Kona, Cour d'appel d'Abidjan, 22 août, 1952, Penant 1954.

37 Achi N'Cho c. N'Bassaidje, Cour d'appel d'Abidjan, 23 avril, 1954, Penant 1955, 301

38 Ministère public c. X, Cour d'appel d'A. O. F., 5 septembre, 1924, Penant, 1925, 11.
} 
of the "statut personnel". From the legislation providing for the option no such limitation appears and, moreover, certain decrees recognized the right of persons of "statut personnel" to celebrate their marriage in accordance with the Civil Code ${ }^{39}$.

\section{The Application of French Law where Customary Law offers no solution or an inadequate solution}

Where customary law provided no adequate solution, the judge could resort to French law as ratio scripta. This filling in of the lacunae of customary law could lead to modification of traditional institutions. This rule was laid down in decrees relating to judicial organization. It was usually provided that French law should be applied in any case where there are no provisions for the case by law or native $\mathrm{law}^{40}$. An example of such an application of this principle was the case of Ebongue c. Edoukou ${ }^{41}$. The facts of the case were that the defendant had insured his lorry against road accidents. While his driver was out, the defendant's brother, employed by him as apprentice, drove the lorry at an excessive speed and collided with another lorry. The plaintiff, who was in the other lorry and had sustained serious injuries, sued the defendant. Consultation with those versed in Douala law (as the customary law of the parties) revealed that in such circumstances it recognized the liability of the person who drove the lorry but not that of the defendant as the owner of the vehicle. The court nevertheless awarded damages against the defendant, basing its decision firstly on the grounds of public order, secondly on the implied intention to submit to French law and finally on the ground that the contract of insurance was unknown to customary law. A precedent for this decision could have been found in a decision of the "Cour de cassation ${ }^{42}$ " which held that in a case between persons of "statut personnel" the rules of article 1384 of the Civil Code, concerning the liability of principals for the damage caused by their agents, was of "ordre public" and therefore binding on all parties no matter their status ${ }^{43}$.

The method of filling in the gaps of customary law was used mainly in cases of contracts and delictual liability. The Civil Code has fairly reasonable principles concerning obligations (Art. 1101 et seq.) and a certain rational appeal. It is therefore not very difficult to understand why a French jurist would apply the code when customary law, which is largely unwritten, is silent or obscurce on the rule to be applied in a particular case. But the extension of this principle to family law could be questioned when, for example, the courts applied the rules of community property to Islamic spouses even though their marriages were polygamous ${ }^{44}$.

39 Decrees of 19 November 1947 modifying the Penal Code of A. O. F., A. E. F., Togo and Cameroun.

40 Decree of 22 November 1922, Art. 67, Penant, 1923, III, 86; see also the note by Lampué at p. 158, Penant, 1934

41 Penant, 1934, 157.

42 Cass. Rég. 27 mars 1922, Penant 1922, I, 215.

43 Code Civil, Art. 1384: "On est responsable non seulement du dommage que l'on cause par son propre fait, mais encore de celui qui est causé par le fait des personnes dont on répond ou des choses que l'on a sous sa garde".

44 Trib. Cir. de Dakar, 23 décembre, 1897, Dareste 1898, III, 63; Cour d'appel de St. Louis, 17 juin, 1898, Dareste 1899 , III, 45. 


\section{E. Exclusion of Customary Law on the grounds of "ordre public"}

In most legal systems there are certain rules from which those subject to them are not allowed to withdraw. For example, most of the rules concerning marriage are obligatory and a person cannot on his own vary or evade them. Such rules are said to constitute "ordre public interne".

In private international law, a party's personal law (based on either domicile or nationality) governs some parts of his legal relations. Even though the personal law is allowed to operate in a territory other than that of his nationality or domicile, such a law will not be given extra-territorial effect if it violates rules which have been made to preserve morality and essential public or social institutions. Such rules bind all persons in the given territory, whether citizens or not, whether domiciled there or elsewhere. Such rules constitute the "ordre public international".

Apart from these two variants of the concept of "ordre public", there was the "ordre public colonial" with which we are mainly concerned. "Ordre public colonial" implied that the law of the "statut personnel" which the colonizing state intended to respect, could not prevail if it infringed or contradicted a rule which the colonial power considered to be essential for the successful fulfilment of the work of colonization. Proceeding from this policy, the colonial power reserved to itself the power to set aside provisions of customary law which it did not approve of and to borrow from French law when customary law was silent or defective.

The legislative authority for the notion of "ordre public colonial" was found in decrees concerning judicial organization in the colonies ${ }^{45}$. It was usually provided that the customary courts should apply the law and local customs, "en tout ce qu'elles n'ont pas de contraire aux principes de la civilisation française". The arrogance of such assumptions leaves one breathless. But it was in the logic of the colonial enterprise to deny the existence of any values in the culture of the African societies: As Fanon declared: "Il ne suffit pas au colon de limiter physiquement, c'est-à-dire à l'aide de sa police et de sa gendarmerie, l'espace du colonisé. Comme pur illustrer le caractère totalitaire de l'exploitation coloniale, le colon fait du colonisé une sorte de quintessence du mal. La société colonisée n'est pas seulement décrite comme une société sans valeurs. Il ne suffit pas au colon d'affirmer que les valeurs ont deserté, ou mieux n'ont jamais habité, le monde colonisé. L'indigène est déclaré imperméable à l'éthique, absence de valeurs, mais aussi négation des valeurs ${ }^{40}$ ".

The content and extent of the notion of "ordre public" varied according to time and place. The customary laws in West Africa were many and different and there was no question of applying a uniform solution to all of them. Certain institutions, such as polygamy, were generally considered to be contrary to French civilization but could not be declared unlawful since attempts at their suppression would have raised too many problems and the resistence of many people who did not see why some European who could not even understand the simplest fact of African life should come and tell them how many wives they should have. The notion of

45 Decrees of 16 August 1912, Art. 36 (Penant, 1912, III, 282); 13 April 1921, Art. 20 (Penant, 1912, III, 43); 22 November 1922, Art. 67 (Penant, 1923, III, 86); See also the decrees providing a system of registration of contracts made by Africans - 2 May 1906 (Penant 1906, III, 172); 29 September 1920 (Penant 1921, III., 25).

46 Frantz Fanon, Les damnés de la terre, Paris, Maspero, 1961, 33. 
public policy was used mainly to set aside customs which appeared to the courts to disrespect human dignity and personality. Thus the Cour d'appel of Dakar held it to be contrary to the law for a tribunal to recognize the proprietary right of one person over another. Even if such a right were recognized by Islamic law or traditional law, it was contrary to the principles of French civilization ${ }^{47}$. Similarly, the custom of placing with a third person a member of one's family as guaranty for the payment of a debt was held to be contrary to French civilization since it tended to prejudice individual liberty ${ }^{48}$. In the field of family law the courts were often faced with situations which, for the European, were difficulty to classify. They limited individual liberty and yet one could not say that they amounted to. the alienation of the liberty of a third party. In one case the court held that the decrees which dealt with the suppression of slavery did not affect paternal rights, rights of tutelage, marital rights over women and children so long as those rights did not amount to enslavement of the persons involved 49 . Thus even though the practice of marrying off a woman without her consent was contrary to French civilization, it could not be considered as slavery. But a custom conferring on a head of family the right to inflict punishment (in this case, corporal punishment in public) was contrary to "ordre public ${ }^{50}$ ".

The concept of "ordre public" was also used to help the evolution of customary law. This use of the concept may be illustrated by a case from Mauritania ${ }^{51}$. Two persons negligently put a lorry into motion and as a result a third person died from injuries. The customary law of the accused who belonged to the same tribe would in such cases hold the whole tribe collectively responsible. The tribe was divided into three groups, one of which refused to pay its share. The principle of collective liability was rejected by the court which argued that although the law guaranteed the maintenance of the "statut personnel", its rules need not be applied if they were incompatible with not only social realities but also with the principles of French law and "ordre public". Individual responsibility, both civil and criminal, was basic to French law and had been embodied in the Penal Code which applied to all. So if customary law imposed collective liability, it depended on the goodwill of the collectivity whether it would make reparation or not.

\section{Changes made by the 1946 Constitution in the matter of Status}

Article 80 of the French Constitution of 1946 generalized citizenship by extending it to all the inhabitants of the French Union without regard to their status in private law:

"Tous les ressortissants des Territoires d'Outre-Mer ont la qualité de citoyen au même titre que les nationaux français de la Métropole ou des Territoires d'Outre-Mer. Des lois particulières établiront les conditions dans lesquelles ils exerceront leurs droits de citoyen".

\footnotetext{
47 Cour d'appel d'A. O. F., 14 November 1905, Penant, 1906, 79.

48 Cour d'appel d'A. O. F., 12 November, 1912, Penant, 1913, 85.

49 Cour d'appel d'A. O. F., 30 June 1914, Penant, 1914, 328.

50 Chambre spéciale d'homclogation du Cameroun, 1 février, 1933, N'Doumba Doula et autres, Penant $1934,157$.

51 Trib. Colonial d'appel de la Mauritanie, 30 septembre, 1953, Sidiya Ould Mohamed Abderrahmane contre Mohamed El Motar Ould Mohamed El Hacen, Penant, 1956.
} 
Article 82 of the Constitution made provisions for the preservation of the "statut personnel": "Les citoyens qui n'ont pas le statut civil français conservent leur statut personnel tant qu'ils n'y ont pas renoncé". The effect of these articles was to abolish the distinction between citizens and non-citizens which corresponded to the distinction between "statut personnel" and "statut civil français". Thenceforth a citizen could keep his "statut personnel" so long as he had not renounced it. If he renounced it, he could assume the "statut civil français" under the following conditions: he had to be over twenty-one years old, be a bachelor or married to one woman. (Those who were polygamously married were thus excluded ${ }^{52}$.) The new citizen had to be capable of understanding the effects of the change of status. No discretionary power was given to the administration ${ }^{53}$.

\section{Conclusion}

The French colonial system was in no way well disposed to traditional law and institution. It was in the nature of colonialism and imperialism to subordinate African law to European law, to eliminate the indigenous law from the areas of public law where the legitimacy of colonial domination (born in violence and maintained by violence) might be questioned by indigenous rules of egalitarian and democratic government. But even in the field of private law where in theory African law was given a wide scope of application, the tendency was to limit and hinder its application where it came into conflict with French conceptions, considered by the colonialists to be principles of a higher civilization. Notions such as "ordre public" (equivalent to the British colonial limitation expressed by the phrase: "repugnant to natural justice, equity and good conscience") were used to justify the elimination of traditional law from cases where it would otherwise apply.

Despite various declarations and proclamations about French assimilation policy, a class and race barrier was erected by dividing the population into citizens and non-citizens, each living in its own world: No one has put it better than Frantz Fanon:

"Ce monde compartimenté, ce monde coupé en deux est habité par des espèces différentes. L'originalité du contexte colonial, c'est que les réalités économiques, les inégalités, l'énorme différence des modes de vie, ne parviennent jamais à masquer les réalités humaines. Quand on aperçoit dans son immédiateté le contexte colonial, il est patent que ce qui morcèle le monde c'est d'abord le fait d'appartenir ou non à telle espèce, à telle race. Aux colonies l'infrastructure économique est également une superstructure. La cause est conséquence: on est riche parce que blanc, on est blanc parce que riche ${ }^{54}$."

That there was no serious intention on the part of the colonial authorities to assimilate the African population was obvious. The conditions for such an "elevation" in status could hardly be fulfilled by more than a small percentage of the

\footnotetext{
52 African anthropologists must give us one day an objective and detailed account about the constant. European preoccupation with sex and polygamy in the colonies. It may be necessary to look into the society from which the colonialists came in order to establish whether these characteristics were derived from the native communities and tribes of the colonialists or whether they developed them in the colonial situation.

53 Avis du Conseil d'Etat, 22 novembre 1955, Penant, 1940.

54 Op. cit. p. 32.
} 
population, given the inadequate educational facilities which existed in the colonies. But what gave the Europeans the right to set themselves up as masters, to determine who was civilized and who was not?

It is usual in discussing colonial policy to contrast the French policy of assimilation with the British policy of indirect rule ${ }^{55}$. Certainly, one must admit that the different colonial policies have left dissimilar styles of administration in the postcolonial states ${ }^{56}$. But when one considers matters from a purely African point of view, i. e. the preservation of African culture and interests, the differences between French and British colonial rule become insignificant: both colonial powers succeeded in interrupting the course of development of African institutions, deprived Africans of their basic liberties, and imposed on them European languages, culture and law ${ }^{57}$.

\footnotetext{
55 Crowder, op. cit. pp. 233-235. against the temptation of saying that one colonial system is better or more humane than the other. For example, Padmore, Panafricanisme ou Communisme (Paris, 1960, 197-219) seems to think that the British colonial system was the best of all while A. Meister, L'Afrique peut-elle partir? (Paris, 1966, 89-90) considers the French assimilation policy to have placed the African in a better position for independence. This type of comparison diverts attention from discussing the basic evil of colonialism and tends to look for the explanation of disastrous events in the defencies of individuals, nations or governments, instead of examining the system which make such events possible. The same comment applies to the question whether the French were less racist than the British. As Fanon said, a society is racist or not. (Teau noire masque noire, Paris, 1952, p. 89).

57 "Les faits montraient une remarquable convergence dans les résultats effectifs de la colonisation, qu'elle fût anglaise uu française”, G. Leclerc, Anthropologie et Colonialisme, Fayard, Paris, 1972, p. 129.
} 


\section{By Zdenek Červenka}

In the field of peaceful settlements of disputes, the record of the OAU is certainly more impressive than that of the United Nations Organisation. One of the most interesting aspects of the OAU's handling of disputes and crises has been the fact that these disputes and crises were resolved not by the organ created specially for that purpose, the "Commission of Mediation, Conciliation and Arbitration", but by political negotiations which in most cases were based on the private initiative of African leaders. African leaders enjoying the status of "leaders of opinion" in Africa, men of stature - Emperor Haile Selassie of Ethiopia, the late President William Tubman, and most recently the most successful officers turned politicians - Presidents Mobutu of Zaire and General Gowon of Nigeria.

The OAU thus evolved its own mechanism for the peaceful settlement of disputes, the essence of which has been diplomacy rather than rules of law. Its main features are:

1. Emphasis on the settlement within the African framework, excluding any outside interference.

2. Employment of the "top level" authority of an individual Head of State or a group of Heads of State.

3. The laying down of guiding principles to be applied in various situations leading to a conflict

The resolutions adopted by the OAU on "Border Disputes" among African States, "Declaration on the Problem of Subversion and the Resolution on the Problem of Refugees in Africa" are examples of the rules agreed upon by the OAU MEMBERS. The article also analyses the problem of the "recognition of new regimes" which came to power by coups d'état and which too gave rise to disputes and even conflicts. However, in most cases the "legality" always gave way to "reality".

Finally, the author raises the question regarding the future of the Commission of Mediation, Conciliation and Arbitration, which he sees in a gradual process of getting involved in the political settlement of disputes and providing the political leaders, charged with the task of settling a particular dispute, with qualified legal advice.

\section{Traditional Law Under French Colonial Rule}

\section{By Kwame OPOKU}

Despite all declarations of their intention to respect African institutions, the French subordinated African law to French law. They divided the inhabitants of their colonies in West Africa into two groups: citizens and non-citizens. French citizens were subject to French law and non-citizens were governed by African law. The inhabitants of the old communes of Senegal (Dakar, Gorée, St. Louis and Rufisque) were granted citizenship but allowed to settle their private law matters in accordance with African traditional law. Africans in other parts of the colonies 
could acceed to citizenship by various methods which by their very nature prevented too many persons from becoming citizens. The main effect of change of status was that the African became thenceforth subject in principle to French law.

There were cases where French law was applicable to non-citizens. For example, when a Frenchman and an African were involved in a dispute, then French law applied. Moreover, parties to a dispute, whether citizens or not, could in some situations agree to submit the matter to the French courts. In situations where customary law did not offer an adequate solution, the courts would apply French law. Customary law could be excluded if its solution offended French notions of public order.

The main effect of the introduction of French law was to interrupt the development of African institutions.

\section{Constitution and Politics in Senegal Since Independence}

\section{By Klaus Ziemer}

Although the same President of the Republic and the same political party have been in power in Senegal since independence in 1960, the political institutions have undergone several fundamental changes. After the 1960 constitution, which introduced a dual executive modelled on the constitution of the Fifth French Republic, the constitution of the "Second Senegalese Republic" concentrated in 1963 all executive power in the hands of the President of the Republic. In contrast, a new constitutional reform in 1960 set up a very week governement in the system of a so-called "pouvoir exécutif déconcentré". The power of the National Assembly was curtailed not only by the text of the constitutions, but above all by the existence of the UPS, single dominant party until 1966, since then the only legally constituted party. All constitutional changes were the results of political crises without being able to abolish their causes. The centre of political power has not yet been able to gain enough control over the peripheral sectors of the political system. As the production of groundnuts has diminished because of drought and the price on the world market has sunk in the last few years, private and public income have fallen, which has caused some unrest among the peasants and reinforced the power of Islamic marabouts who established themselves as a link between the political centre and the masses whom they control. On the other hand, the still only weakly organized UPS tries to integrate the opposition trade unions. Senegal is passing through a period of transition, marked by the efforts of the central political authorities to consolidate their power and to secure a smooth succession of the President of the Republic and General Secretary of the UPS, Léopold Sédar Senghor. 